Князев О. А.

Одеська національна академія зв’язку імені О. С. Попова, Одеса, Україна

\title{
ОЦІНКА РЕЗУЛЬТАТИВНОСТІ ВПРОВАДЖЕННЯ КОМПЛЕКСНИХ СИСТЕМ ФІЛЬТРАЦІЇ КОНТЕНТУ
}

\begin{abstract}
У роботі доведено, що інформаційні ризики, а саме кіберпреступність, відносяться до основних проблем сучасного цифрового простору. Одним із проявів кіберзагроз є присутність небажаного або недозволеного контенту в мережі Інтернет, що призводить до втрат соціального, економічного, технологічного й особистісного характеру. Це, у свою чергу, призводить до зниження продуктивності праці бізнес-одиниць, зниженню ділової активності, проблемам у приватних осіб через збільшення витрат на подолання наслідків кіберпреступності. Для запобігання цих втрат необхідно розробляти й впроваджувати комплексні системи фільтрації контенту (КСФК). Тому мета роботи пов'язана з розробкою підходів до оцінки результативності впровадження КСФК. Фільтрація небажаного контенту дозволяє одержувати не тільки технологічний результат. Обмеження доступу до шкідливих ресурсів призведе до виникнення й інших видів результативності. У роботі доведено, що впровадження КСФК призведе до виникнення фінансово-економічної, ресурсної, соціальної, екологічної, поліхромної та технічної результативності. Наведено аналіз показників результативності, яка виникає на різних рівнях - для населення, підприємств і держави в цілому. Одержала подальший розвиток існуюча система індикаторів оцінки технологічної результативності впровадження КСФК шляхом додавання показників вартості та рівня адаптивності (гнучкості). Показано векторну спрямованість існуючих і пропонованих індикаторів. Представлено підхід до визначення запропонованих індикаторів оцінки результативності впровадження КСФК і наведений приклад розрахунку комплексного показника результативності. Висловлено припущення, що в результаті впровадження КСФК можлива поява синергетичного ефекту, що полягає в зростанні сукупного результату за рахунок загальної дії всіх елементів системи, що в підсумку приводить до збільшення якісних характеристик функціонування КСФК без збільшення кількісних.
\end{abstract}

Ключов і слов а : комплексна система фільтрації контенту, результативність, впровадження, вартість, адаптивність.

\section{Вступ}

Постановка проблеми у загальному вигляді. Сучасному суспільству, яке стоїть на шляху формування глобального інформаційного середовища, притаманні різні ризики, які характерні для цифрового світу. Серед першорядних, поряд економічними та екологічними, можна визначити інформаційні ризики, а саме ризики, які пов'язані з кіберзлочинністю. Наявність цих ризиків турбує суспільство в цілому, представників влади та бізнес-середовища, приватних користувачів. В Законі України «Про Стратегію кібербезпеки України» визначається, що «сучасні інформаційно-комунікаційні технології можуть використовуватися для здійснення терористичних актів, зокрема шляхом порушення штатних режимів роботи автоматизованих систем керування технологічними процесами на об'єктах інфраструктури» [1].

Одним 3 проявів кіберзагроз є наявність небажаного та/чи несанкціонованого контенту в мережі Інтернет. Користувачі мережі Інтернет перманентно стикаються 3 такими загрозами як віруси та інші шкідливі об'єкти, мережеві атаки, перехоплення паролів і фітинг, витік важливого контенту, кіберпереслідування тощо. Ці та інші прояви призводять до різних за масштабами втрат соціального, економічного, технологічного, особистісного характеру. Це, в свою чергу, спричиняє скорочення ефективності діяльності суб'єктів економічної діяльності та приватних осіб за рахунок збільшення витрат на подолання наслідків кіберзлочинності. Одним 3 технологічних рішень проблеми кіберзлочинності є використання технологій фільтрації контенту в мережі Інтернет. Виходячи з вищеозначеного, виникає нове науково-прикладне завдання, пов'язане із визначен- ням результативності впровадження комплексних систем фільтрації контенту (КСФК) та застосування КСФК в мережі Інтернет. Наявність цього завдання обумовлює актуальність тематики статті.

Аналіз останніх досліджень. Питання обгрунтування та оцінки результативності реалізації методів фільтрації небажаного контенту в мережі Інтернет $є$ недостатньо вирішеними виходячи з відносної новизни визначеної проблематики. Так, до наукових доробок $з$ цього питання можна віднести праці С. Вахоніна, В. Каптура, В. Шевченка та інших [2-5]. В цих працях сформовано наукове бачення та прикладні підходи щодо ефективності застосування контентної фільтрації та ефективної оцінки універсального ідентифікатору ресурсу (Universal Resource Identifier, URI) в комплексних системах фільтрації контенту, зокрема, з точки зору національної безпеки. Також ці наукові розробки дозволяють стверджувати, що ефективність систем фільтрації контенту та самого процесу фільтрації в цілому залежить не тільки від якості методів, що застосовуються, а й від якості й повноти функціональних можливостей контролю по контекстних параметрах 3 точки зору можливості перехоплювати, блокувати й протоколювати передачу даних на рівні протоколів, портів і пристроїв, які логічно передують контентному аналізу, тобто від якості й ефективності архітектури системи [2].

Визначимо, що ефективність має на увазі відношення отриманих результатів до витрат, а результативність свідчить про ступень реалізації чи досягнення очікуваних результатів. У нашому випадку (в процесі впровадження КСФК) мова їде не лише про економічні результати, а про технічні, соціальні аспекти, питання безпеки та захисту, тому предметом дослідження $€$ саме результативність впровадження КСФК. 
Недостатня вирішеність питань, присвячених формуванню методів та підходів щодо оцінки результативності впровадження КСФК, визначає мету роботи, пов'язану із розробкою відповідних підходів.

\section{Виклад основного матеріалу дослідження}

В сучасному суспільстві при оцінці результативності будь-яких процесів не достатньо лише економічних показників, оскільки соціальна спрямованість техніко-економічних процесів призводить до необхідності задоволення вимог споживачів та дотримання принципів соціальної відповідальності бізнесу. Тому виникають категорії соціальноекономічного, технологічного, ресурсного ті інших результатів. Ці категорії безпосередньо стосуються й процесів фільтрації контенту, оскільки в процесі фільтрації кінцевий споживач отримує низку різних видів результату. При цьому ці результати виникають на різних рівнях, а саме на рівні держави, підприємств та приватних споживачів.

Міжнародний союз електрозв'язку (МCE) проводить щорічний моніторинг та формує Звіт «Глобальний індекс кібербезпеки та профілі щодо кіберблагополуччя (ГІК)», в якому визначає Глобальний індекс кібербезпеки кожної країни за групами показників - законодавчих, технічних, організаційних, соціальних та міжнародних. За цією системою оцінки Україна посідає 59 місце з ГІК, що дорівнює 0,501 [6]. Виходячи 3 показників, які ураховуються при формуванні ГІК, можна стверджувати, що існує необхідність визначення не лише результату від заходів щодо забезпечення кібербезпеки без посеред- ньо, а й результативності реалізації окремих складових показника ГІК, а саме від впровадження КСФК. Спираючись на склад показників ГІК, впровадження КСФК та позитивний результат від цього здатні забезпечити нарощування потенціалу кібербезпеки за групою технічних показників та сприяти розвитку інших складових оцінки ГІК.

Дослідження науковців свідчать, що фільтрація небажаного контенту дозволяє отримати не лише суто технологічні результати у вигляді затримки забороненої інформації та/чи доступу до шкідливих інформаційних ресурсів $[2,3]$. Обмеження доступу до шкідливих ресурсів сприяє появі і інших результатів. Так, використання засобів захисту інформації на транспорті збільшує його пропускну спроможність завдяки обмеженню ризиків потрапляння небезпечного чи шкідливого програмного продукту в систему управління логістикою. У сільському господарстві оснащення засобами зв'язку машинного парку и польових бригад знижує нецільові втрати робочого часу та простої на $20 . . .40 \%$. Якісно організований зв'язок у системі управління будівництвом дозволяє підвищити продуктивність праці не менше ніж на $15 \%$ [7].

В даній роботі визначено, що в процесі впровадження різних проектів в сфері інформаційнокомунікаційних технологій (IКТ), зокрема фільтрації контенту, виникають різні прояви результативності цього процесу. Ураховуючи, що метою впровадження КСФК є запобігання шкоди від потрапляння небажаного контенту в сфері IКT, а також в усіх сферах життєдіяльності суспільства, визначено, що результативність впровадження КСФК складається із складових, які систематизовано та наведено у табл. 1.

\section{Таблиия 1 - Складові результативності впровадження КСФК на різних рівнях запровадження}

\begin{tabular}{|c|c|c|c|c|}
\hline \multirow{2}{*}{$\begin{array}{c}\text { Результа- } \\
\text { тивність }\end{array}$} & \multirow{2}{*}{$\begin{array}{c}\text { Змістовне } \\
\text { наповнення }\end{array}$} & \multicolumn{3}{|c|}{ Рівень виникнення } \\
\hline & & Населення & Підприємства & Держава \\
\hline $\begin{array}{l}\text { Фінансово- } \\
\text { економічна }\end{array}$ & $\begin{array}{l}\text { Враховує усі можливості } \\
\text { максимізації результатів } \\
\text { та мінімізації витрат, які } \\
\text { можуть виникати в ре- } \\
\text { зультаті } \\
\text { КСФК }\end{array}$ & $\begin{array}{l}\text { Скорочення витрат на } \\
\text { придбання різних систем } \\
\text { КСФК }\end{array}$ & $\begin{array}{l}\text { Скорочення витрат часу } \\
\text { на обробку інформації, } \\
\text { зростання продуктивнос- } \\
\text { ті праці, покращення } \\
\text { фінансових показників за } \\
\text { рахунок економії }\end{array}$ & $\begin{array}{l}\text { Сталий розвиток держа- } \\
\text { ви за рахунок підвищен- } \\
\text { ня ефективності діяльно- } \\
\text { сті економічних агентів }\end{array}$ \\
\hline Ресурсна & $\begin{array}{l}\text { Показує вплив фільтрації } \\
\text { інформаційного ресурсу } \\
\text { на обсяг виробництва і } \\
\text { споживання того або іншо- } \\
\text { го виду ресурсу }\end{array}$ & $\begin{array}{l}\text { Більш ефективне вико- } \\
\text { ристання інформаційних } \\
\text { ресурсів у побуті, скоро- } \\
\text { чення витрат домогоспо- } \\
\text { дарств на енергоносії }\end{array}$ & $\begin{array}{l}\text { Оптимізація власної ре- } \\
\text { сурсної бази (технологіч- } \\
\text { ної, кадрової, інформа- } \\
\text { ційної та фінансової), } \\
\text { більш ефективне викори- } \\
\text { стання ресурсів }\end{array}$ & $\begin{array}{l}\text { Зростання ефективності } \\
\text { використання внутрішніх } \\
\text { інформаційних ресурсів, } \\
\text { підвищення інвестиційної } \\
\text { привабливості країни за } \\
\text { рахунок прозорості та } \\
\text { захищеності інформації }\end{array}$ \\
\hline $\begin{array}{l}\text { Соціально- } \\
\text { екологічна }\end{array}$ & $\begin{array}{l}\text { Враховує нові соціальні } \\
\text { та екологічні результати } \\
\text { реалізації проекту }\end{array}$ & $\begin{array}{l}\text { Соціальний захист гро- } \\
\text { мадян, захист дитини в } \\
\text { Інтертнет-середовищі, } \\
\text { зростання довіри насе- } \\
\text { лення до влади }\end{array}$ & $\begin{array}{lr}\text { Підвищення } & \text { іміджу під- } \\
\text { приємства, } & \text { розвиток } \\
\text { соціальної } & \text { відповідаль- } \\
\text { ності бізнесу, скорочення } \\
\text { паперового документоо- } \\
\text { бігу }\end{array}$ & $\begin{array}{l}\text { Створення умов для роз- } \\
\text { витку соціальної відповіда- } \\
\text { льності бізнесу, соціально- } \\
\text { го захисту громадян, довіри } \\
\text { населення до влади, ско- } \\
\text { рочення електромагнітного } \\
\text { випромінювання }\end{array}$ \\
\hline Поліхромна & $\begin{array}{l}\text { Показує економію часу, } \\
\text { що виникає при одночас- } \\
\text { ному використанні різних } \\
\text { методів фрільтрації контен- } \\
\text { ту }\end{array}$ & $\begin{array}{l}\text { Скорочення часу на по- } \\
\text { шуки оптимальної систе- } \\
\text { ми захисту інформації та } \\
\text { системи фрільтрації кон- } \\
\text { тенту }\end{array}$ & $\begin{array}{l}\text { Економія та оптимізація } \\
\text { робочого часу, можли- } \\
\text { вість перерозподілу ро- } \\
\text { бочого часу }\end{array}$ & $\begin{array}{l}\text { Прискорення НТП та } \\
\text { інноваційного розвитку } \\
\text { держави за рахунок оп- } \\
\text { тимізації мережевих ре- } \\
\text { сурсів }\end{array}$ \\
\hline Технічна & $\begin{array}{l}\text { Поява технічних можли- } \\
\text { востей щодо процесу фі- } \\
\text { льтрації контенту: точність } \\
\text { блокування, надійність } \\
\text { (рівень захисту від обхо- } \\
\text { ду), живучість }\end{array}$ & $\begin{array}{l}\text { Підвищення комп'ютер- } \\
\text { ної грамотності населен- } \\
\text { ня, зростання освіченості } \\
\text { громадян щодо ІКТ, точ- } \\
\text { ність блокування неба- } \\
\text { жаного контенту } \\
\end{array}$ & $\begin{array}{l}\text { Відповідність технологій } \\
\text { вимогам НТП та ринку, } \\
\text { відповідність світовим } \\
\text { стандартам, захист від } \\
\text { обходу фільтрів, живу- } \\
\text { чість }\end{array}$ & $\begin{array}{l}\text { Відповідність світовим } \\
\text { стандартам, забезпечен- } \\
\text { ня інформаційної безпе- } \\
\text { ки держави, геополітич- } \\
\text { ний чинник }\end{array}$ \\
\hline
\end{tabular}


Безумовно, фінансово-економічна, ресурсна та інші види результативності впровадження КСФК мають велике значення для процесів впровадження та подальшої діяльності КСФК. Але в даній роботі увагу зосереджено на технічній результативності, оскільки цей напрямок є об'єктом наукового інтересу автора. Так, у попередніх дослідженнях [8], встановлено, що окрім суто технологічних питань конфігурації КСФК, виникає завдання формування системи показників оцінки результативності роботи КСФК. Базуючись на працях $[3,8,9]$, автором систематизовано перелік ключових показників для оцінки результативності впровадження КСФК. До таких віднесено:

- додаткова затримка, що виникає як наслідок наявності значної кількості елементів КСФК та великих обсягів трафіку, яка потребує заходів щодо скорочення;

- точність блокування, яка визначається здатністю КСФК блокувати ресурс, який найбільш повно відповідає заданим критеріям блокування, залишаючи при цьому споживачу можливість доступу до інших ресурсів, тобто не наносячи шкоди іншим доступним ресурсам та правам споживачів на вільний доступ до мережі;

- надійність, яка у даному контексті визначається рівнем захищеності від можливостей обходу та може бути забезпечена різним за складністю програмним забезпеченням, спрямованим на моніторинг трафіку;

- живучість, тобто здатність КСФК до збереження своїх основних функцій (із можливістю втрат якості) в несприятливих впливах із ймовірністю повної відмови доступу в Інтернет для користувачів у випадках, коли доступ до небажаного контенту має більш шкідливі наслідки, ніж повна заборона контенту (наприклад, у випадках необхідності забезпечення безпеки дитини у мережі).

Ці показники, які вже частково досліджені у [8], на нашу думку, потребують доопрацювання шляхом їх доповнення наступними показниками:

- вартість впровадження КСФК (що відповідає Рекомендаціям МСЕ до мереж майбутнього [10]), яка може бути визначена шляхом порівняння вартості існуючих систем захисту з пропонованими КСФК (вартість останніх розраховується шляхом прямої калькуляції витрат на розробку, реалізацію та впровадження КСФК);

- рівень адаптивності (гнучкості) КСФК, який може бути визначено через частку змін, які необхідно здійснити в усіх елементах системи задля адаптації системи до нових вимог.

Розглянемо векторну спрямованість існуючих та запропонованих в даній роботі показників оцінки результативності впровадження КСФК, а також одиниці їх виміру (табл. 2). Як випливає 3 табл. 2, показники, які $\epsilon$ складовими системи оцінки результативності впровадження КСФК, мають різну спрямованість (тобто прагнуть до максимізації чи до мінімізації). Тому виникає необхідність приведення різних показників до вигляду, що надає можливість формування комплексного показника результативності впровадження КСФК. Це можна здійснити шляхом формування однакових (наприклад, відсоткових, що прагнуть до максимізації) вимірів результату. Тому запропоновано наступний підхід до розрахунку визначених показників оцінки результативності впровадження КСФК.

Таблиия 2 - Векторна спрямованість показників результативності впровадження КСФК

\begin{tabular}{|l|l|c|}
\hline \multicolumn{1}{|c|}{ Показники } & \multicolumn{1}{|c|}{ Сутність, одиниця виміру } & Векторна спрямованість \\
\hline Додаткова затримка & час затримки у випадку перевантаження, секунди & $\min$ \\
\hline Точність блокування & частка вірно заблокованих ресурсів, \% або частка одиниці & $\max$ \\
\hline Надійність & частка випадків захисту від обходу КСФК, \% або частка одиниці & $\max$ \\
\hline Живучість & ймовірність збереження функцій, \% або частка одиниці & $\min$ \\
\hline Вартість & відповідно до кошторису, грн. & $\min$ \\
\hline Рівень адаптивності & частка необхідних змін системи, \% або частка одиниці \\
\hline
\end{tabular}

1. Додаткова затримка (Additional delay, $A D$ ) розраховується як відношення існуючої затримки, яка розраховується для кожного конкретного $i$-го випадку виявлення небажаного контенту $\left(A D_{i}\right)$, до середньої $\left(A D_{a v}\right)$ у даному класі задач (з точки зору використання чорних або білих списків):

$$
A D=A D_{i} / A D_{a v} .
$$

У даному випадку оптимальна додаткова затримка прагне до мінімуму. Оскільки, за визначених вище умов максимізації результатів, показники прагнуть до максимізації, формулу (1) необхідно відкоригувати наступним чином (2):

$$
A D^{c o r}=1-A D_{i} / A D_{a v} .
$$

2. Точність блокування (Accuracy of blocking, $A B)$ визначається прямим розрахунком частки вірно заблокованих ресурсів за певний термін часу $(A B)$.
3. Надійність (Reliability, $R$ ), або відсоток (частка) випадків захисту від обходу КСФК $(R)$, також визначається прямим розрахунком частки випадків захисту від обходу систем фільтрації, що прагне до максимуму з точки зору забезпечення надійності роботи КСФК.

4. Живучість (Survivability, S), відбиває ймовірність збереження функцій КСФК у несприятливих умовах, або відсоток (частка) вірно заблокованих ресурсів у певний термін часу.

5. Вартість (Cost, C) визначається через відношення кошторису на розробку та впровадження нової КСФК ( $\left.C_{\text {newsystem }}\right)$ до вартості існуючої системи $\left(C_{\text {existing }}\right)(3)$ :

$$
\mathrm{C}=C_{\text {newsystem }} / C_{\text {existing }} .
$$

Слід уточнити, що ураховуючи існуючі інфляційні процеси, доцільно проводити розрахунок кош- 
торисів з урахуванням дисконту, тобто чинників, що впливають на вартість грошових потоків у часі. Тоді формула розрахунку вартості (3) із урахуванням дисконту $(C d)$ матиме такий вигляд (4):

$$
C d=\sum_{t=1}^{n}\left(C_{\text {newsystem }} /(1+r)^{t-1}\right) / C_{\text {existing }},
$$

де $r$ - річна ставка дисконту, яка визначається на основі урахування дисконт-факторів (рівень інфляції, ставка рефінансування Національного банку України, рівень ризику тощо); $t$ - порядковий номер кожного року, за яким відбувається розрахунок; $n-$ кількість перспективних періодів (років), за які проводиться розрахунок.

Для забезпечення максимізації показника вартості формула (4) набуває вигляду (5):

$$
C d^{\text {cor }}=1-\sum_{t=1}^{n}\left(C_{\text {newsystem }} /(1+r)^{t-1}\right) / C_{\text {existing }} .
$$

6. Рівень адаптивності (Adaptability level, $A L^{c o r}$ ), тобто частка необхідних змін системи, яких потребує процес оновлення КСФК під нові вимоги (поява нових загроз). Визначається розрахунком частки еле ментів системи $(A L)$, які потребують модифікації (6):

$$
A L^{c o r}=1-A L .
$$

Ураховуючи наявність низки показників оцінки результативності впровадження КСФК, виникає потреба у формуванні комплексного показника результативності (Complex Indicator of Productivity, $C I P)$. Це можливо здійснити за допомогою уведення для кожного показника його вагового значення (3 дотриманням умов нормування щодо вагових значень показників). Цей показник розраховуватиметься за формулою (7):

$$
C I P=\sum_{i=1}^{m} I_{i} W_{i},
$$

де $I i-i$-й показник оцінки результативності впровадження КСФК; $W i$ - вагове значення $i$-го показника, яке може встановлюватися, наприклад, методом експертних оцінок із урахуванням умови: $\sum_{i=1}^{m} W_{i}=1 ; m-$ кількість показників в системі оцінки (у даному випадку $m=6$ ).

В якості прикладу наведемо розрахунок комплексного показника результативності впровадження КСФК (табл. 3).

Таблиця 3 - Розрахунок комплексного показника результативності впровадження КСФК

\begin{tabular}{|l|c|c|c|}
\hline \multicolumn{1}{|c|}{ Показник } & Розрахункове значення & Вагове значення & Значення із урахуванням ваги \\
\hline Додаткова затримка, $A D^{\text {cor }}$ & 0,85 & 0,05 & 0,0425 \\
\hline Точність блокування, $A B$ & 0,8 & 0,4 & 0,32 \\
\hline Надійність, $R$ & 0,6 & 0,2 & 0,12 \\
\hline Живучість, $S$ & 0,75 & 0,2 & 0,15 \\
\hline Вартість, $C d^{\text {cor }}$ & 0,65 & 0,1 & 0,065 \\
\hline Рівень адаптивності, $A L^{\text {cor }}$ & 0,9 & 0,05 & 0,045 \\
\hline Комплексний показник, $C I P$ & & & 0,7425 \\
\hline
\end{tabular}

Отриманий показник $C I P$ повинен прагнути 1 , тобто $C I P \rightarrow 1$. Оскільки максимальне значення показника $(C I P=1)$ отримати практично неможливо, необхідно встановити шкалу, за допомогою якої можна зробити висновок про достатність отриманих результатів з точки зору доцільності впровадження КСФК. Оскільки для розрахунку CIP використовувалися стандартні підходи із використанням відсоткових значень (або часток), доцільно спиратися на вже іс- нуючі наукові розробки [11], в межах яких визначається критичне (мінімально-припустиме) значення, що дорівнює 0,5. Тобто вважається, що система працює результативно, якщо вона затримує не менш половини небажаного контенту. Результати, які мають значення менше мінімально-припустимого, свідчать про недостатню результативність впровадження КСФК. Пропонуємо таку шкалу інтерпретації результатів розрахунку СIP КСФК (рис. 1).

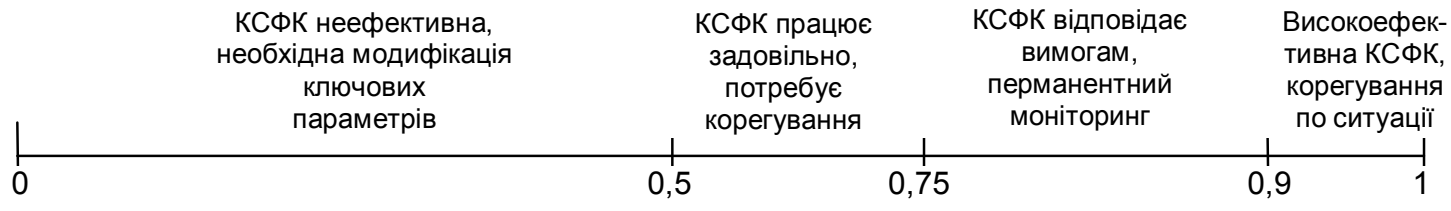

Рис. 1. Шкала інтерпретації результатів розрахунку СІР КСФК (сформовано шляхом опрацювання [11])

Відповідно до наведеної шкали, отримана оцінка СІР КСФК на рівні 0,7425 знаходиться на межі $з$ задовільною. Покращення результативності функціонування потребує перш за все рівень адаптивності системи (на підставі аналізу останнього стовпця табл. 3). Крім того, отримані результати можуть бути візуалізовано у вигляді пелюсткової діаграми, на якій наочно видно, які складові системи оцінки потребують вдосконалення (рис. 2). 3 рис. 2 також ви- дно, що саме рівень адаптивності системи потребує вдосконалення.

Зазначимо, що результативність впровадження КСФК може мати вторинні наслідки у вигляді покращення умов праці та запобігання потрапляння шкідливих програм до користувачів, що призводить до підвищення продуктивності праці, що, в свою чергу, може призвести до додаткових надходжень до бюджету та зростанні ВВП (на макрорівні). 

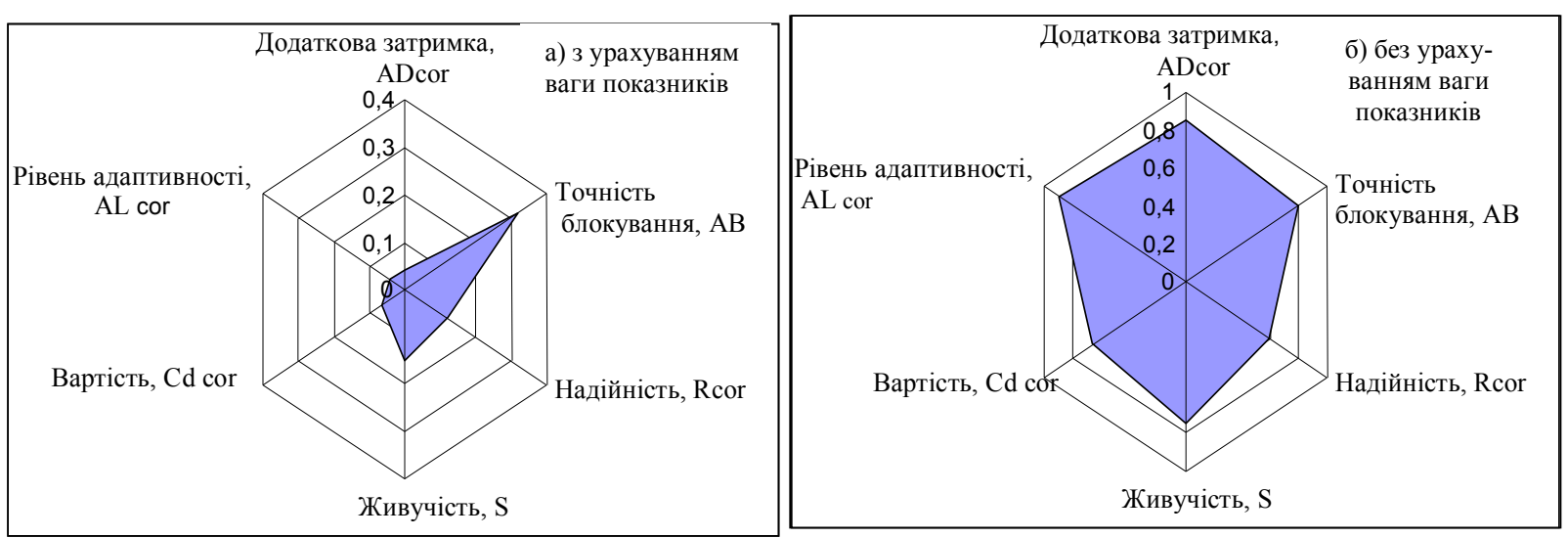

Рис. 2. Складові системи оцінки СІР КСФК (з урахуванням (а) та без урахування (б) ваги показників)

Все це призводить до росту чистого продукту (національного доходу) i, як результат, до загального підвищення макроекономічної ефективності. Так, прискорення процесу фільтрації контенту збільшує швидкість технологічних та бізнес-процесів (зростає технологічна результативність).

Зростання ступеня адаптивності призводить до скорочення часу на модернізацію КСФК, призводячи до підвищення економічної результативності. Зростання ступеню захищеності дитини в мережі сприяє зростанню соціальної результативності i, як наслідок, призводить до виникнення іміджевого ефекту у вигляді зростання ступеню довіри населення до держави та організацій, що сприяють захисту громадян. Тобто можна говорити про наявність синергетичного ефекту від впровадження КСФК, який полягає у зростанні загальної результативності за рахунок спільної дії всіх елементів системи, що призводить до збільшення якісних показників функціонування КСФК без збільшення кількісних.

До найбільш значущих чинників утворення синергетичного ефекту слід віднести такі:

1. Оптимізація витрат виникає за рахунок реалізації саме комплексної системи, яка місить у собі низку заходів задля запобігання різним атакам, тобто виключає витрати на впровадження декількох систем фільтрації.

2. Підвищення задоволеності споживачів, що призводить до зростання обсягів споживання послуг (економічна складова) та захищеності населення та бізнесу від мережевих атак (соціальна складова).

3. Зростання якості надання мережевих послуг та захищеності персональної інформації споживачів, що у свою чергу призводить до відсутності втрат часу та коштів на відновлення втраченої інформації та/чи ділової репутації бізнес-одиниць.

4. Підвищення ділової активності підприємства, яка виникає завдяки прискоренню технологічних та бізнес-процесів, що логічно призводить до зростання його ділової активності та фінансовоекономічних результатів.

5. Вивільнення часу у населення та економія часу підприємців, що виникає у вигляді поліхромного ефекту, тобто економії часу за рахунок одночасного отримання різних засобів захисту від шкідливого контенту за допомогою КСФК.

При цьому чим більше синергетичний ефект від впровадження КСФК, тим глибше соціальна відповідальність організацій, що їх впроваджують, та ступінь соціально-економічної та технологічної взаємодії держави з суспільством.

\section{Висновки}

Проведені дослідження показали, що впровадження КСФК має за мету отримання не лише технологічних результатів у вигляді затримання небажаного контенту. Реалізація КСФК призведе і до отримання низки економічних, соціальних та інших результатів. У статті розглянуто основні складові результативності впровадження КСФК на різних рівнях запровадження. Здійснено аналіз та доопрацювання переліку показників, що характеризують результативність впровадження КСФК шляхом додавання показників вартості (що відповідає Рекомендаціям МСЕ до мереж майбутнього) та рівня адаптивності (гнучкості). Встановлена векторна спрямованість показників та наведено підхід до їх визначення.

Наведено приклад розрахунку результативності впровадження КСФК та обгрунтовано припущення, що впровадження КСФК може супроводжуватися появою синергетичного ефекту.

У подальших дослідженнях планується розробка системи доопрацювання методичного підходу до визначення синергетичного ефекту від реалізації КСФК.

\section{СПИСОК ЛІТЕРАТУРИ}

1. Закон України «Про Стратегію кібербезпеки України». [Електронний ресурс]. Режим доступу: http://zakon5.rada.gov.ua

2. Вахонин С. Эффективность применения контентной фильтрации в DLP-системах / С. Вахонин // Information Security, № 3, 2015. [Електронний ресурс]. Режим доступу: http://www.itsec.ru/insec-about.php

3. Каптур В.А. Формування профілів ефективної оцінки URI в комплексних системах фільтрації контенту / В.А. Каптур, I.А. Поднебесний // Матеріали 14 міжнародної НТК "Вимірювальна та обчислювальна техніка в технологічних процесах", Одеса, 5-10 червня 2015. - РВЦ ХНУ, 2015. - С. 26-28. 
4. Шевченко В.Л. Лучшие мировые практики управления информационной безопасностью и их влияние на экономическую стабильность государства / Сучасні інформаційно-телекомунікаційні технології: матеріали науково-технічної конференції (м. Київ, 17-20 листопада 2015 р.). У 5 томах. - T. IV. Сучасні технології інформаційної безпеки. - Київ, ДУТ, 2015. - С. 5-7.

5. Saravana Balaji B., Amin Salih Mohammed, Chiai Al-Atroshi, “Adaptability of SOA in IoT Services - An Empirical Survey", International Journal of Computer Applications, vol. 182(31), pp. 25-28, 2018, DOI: http://doi.org/10.5120/ijca2018918249

6. Звіт «Глобальний індекс кібербезпеки та профілі щодо кіберблагополуччя». [Електронний ресурс]. Режим доступу: https://www.itu.int/ru/ITU-D/Pages/Global-Cybersecurity-Index-and-Cyberwellness-Profiles-Report.aspx

7. Бутенко А.И. Управление предпринимательством: критерии эффективности / А.И. Бутенко, И.Н. Сараева. - Одесса: Феникс, 2004. - 364 с.

8. Каптур В.А. Показники оцінки ефективності роботи комплексних систем фільтрації контента / В.А. Каптур, О.А. Князєв, К.О. Шестаков // Матеріали 72-ої науково-технічної конференції професорсько-викладацького складу, науковців, аспірантів та студентів ОНАЗ ім. О.С. Попова (13 - 15 грудня 2017 р.). Секція № 4. Інформаційна безпека. - Одеса: ОНАЗ ім. О.С. Попова, 2017. - С. 108-110.

9. Васильків Н. М. Ефективність інформаційних систем [Текст] / Н. М. Васильків. - Тернопіль : Економічна думка, 2005. $-98 \mathrm{c}$.

10. Сети последующих поколений - Структура и функциональные модели архитектуры: МСЭ-Т [Текст]: Международный стандарт электросвязи. - Ү.2001. - [Действителен от 2004-17-12]. - Женева, 2005. - 12 с.

11. Краснокутська Н.С. Потенціал підприємства: формування та оцінка: навч. посібник / Н. С. Краснокутська. - Київ: Центр навчальної літератури, 2005. - 352 с.

Рецензент: д-р техн. наук, проф. С. Г. Семенов, Національний технічний університет “Харківський політехнічний інститут”, Харків Received (Надійшла) 22.11.2018 Accepted for publication (Прийнята до друку) 16.01.2019

\section{Оценка результативности внедрения комплексных систем фильтрации контента}

\section{А. А. Князев}

В работе показано, что информационные риски, а именно киберпреступность, относятся к основным проблемам современного цифрового пространства. Одним из проявлений киберугроз является присутствие нежелательного или неразрешенного контента в сети Интернет, что приводит к потерям социального, экономического, технологического и личностного характера. Это, в свою очередь, приводит к снижению производительности труда бизнес-единиц, снижению деловой активности, проблемам у частных лих из-за увеличения расходов при преодолении последствий киберпреступности. Для предотвращения этих потерь необходимо разрабатывать и внедрять комплексные системы фильтрации контента (КСФК). Поэтому цель работы связана с разработкой подходов к оценке результативности внедрения КСФК. Фильтрация нежелательного контента позволяет получать не только технологический эффект. Ограничение доступа к вредоносным ресурсам приводит к возникновению и других видов результативности. В работе определено, что введение КСФК приведет к возникновению финансового, экономического, ресурсного, социального, экологического, полихромного и технического результата. Приведен анализ показателей результативности, которая возникает на разных уровнях - для населения, предприятий и государства. Получила дальнейшее развитие существующая система индикаторов оценки технологической результативности внедрения КСФК путем введения показателей стоимости и уровня адаптивности (гибкости). Показана векторная ориентация существующих и предлагаемых индикаторов. Предложен подход к определению предлагаемых индикаторов оценки результативности введения КСФК и приведен пример расчета комплексного показателя результативности. Высказано предположение, что в результате внедрения КСФК возможно появление синергетического эффекта, который состоит в росте совокупного результата за счет общего действия всех элементов системы, что в итоге приводит к увеличению качественных характеристиках функционирования КСФК без увеличения количественных.

Ключевые слова: комплексная система фильтрации контента, результативность, внедрение, стоимость, адаптивность

\section{Estimation of productivity from introduction of complex systems of a filtration of a content}

\section{A. Kniaziev}

It is possible to carry information risks, namely cybercriminality to the basic problems of modern digital space. One of displays of cyberthreats is presence of an undesirable or unapproved content in a network the Internet that leads to losses different on scales socially, economic, technological, personal character. It, in turn, causes reduction of productivity of activity of subjects of economic activities and private persons at the expense of increase in expenses at overcoming of consequences of cybercriminality. For prevention of these losses it is necessary to develop and introduce complex systems of a filtration of a content (CSFC). Therefore the work purpose is connected with working out of approaches to an estimation of productivity from introduction of CSFC. The filtration of an undesirable content allows to receive not only technological effect. Access restriction to harmful resources assists occurrence and other kinds of productivity. It is proved that introduction CSFC will lead to occurrence financial and economic, resource, sociallyecological, polychromical and technical productivity. Ordering of the designated productivity at different levels of its occurrence for the population, the enterprises and the state is spent. The existing system of indicators of an estimation of technological overall performance CSFC by cost indexes and level of adaptability (flexibility) is added. The vector orientation of the existing and offered indicators is designated. The approach to calculation of the offered indicators of an estimation of productivity from introduction CSFC is developed and calculation of an complex indicator of productivity is carried out. Occurrence synergetrics effect from introduction CSFC which consists in growth of cumulative effect at the expense of the general action of all elements of system which leads to increase in quality indicators of functioning without increase in the quantitative is proved.

Keywords : complex system of a filtration of a content, productivity, introduction cost, adaptability. 